\title{
Simulasi Visualisasi Teknik Gerakan Yoga Dengan Metode Pengembangan Multimedia Luther-Sutopo Berbasis Mobile
}

\author{
Putra Arya Nanda \\ Program Studi Teknik Informatika, STMIK Budi Darma, Medan, Indonesia \\ Email: ${ }^{1}$ putraaryananda4@gmail.com \\ Submitted 13-01-2020; Accepted 03-02-2020; Published 26-04-2020
}

\begin{abstract}
Abstrak
Saat ini terdapat banyak sekali olahraga salah satunya yoga, yoga sangat bermanfaat buat kesehatan jasmani dan rohani. pada zaman modern ini yoga sangat kurang peminatnya karena kurangnya informasi mengenai teknik gerakan di daerah-daerah tertentu, sehingga menurunkan minat masyarakat dalam mempraktekkan teknik gerakan yoga. Perlu adanya jalan keluar pada permasalahan ini dengan membuat sebuah media Multimedia yang berbentuk visualisasi dan simulasi menggunakan berbasis mobile, Serta menggunakan metode Luther - sutopo yang dimana prosesnya dibagi menjadi 6 tahap yaitu : concept, design, material collecting, assembly, testing, distribution. Sehingga pengembangan multimedia ini dapat dikembangkan dengan berbasis mobile. Penggunaan Media simulasi dan visualisasi Multimedia berbasis mobile membuat user lebih mudah dalam melakukan mengetahui teknik gerakan yoga dikarenakan bentuk simulasi dan viusalisasi gerakan yoga yang menarik bisa meningkatkan minat orang-orang Diharapkan dalam aplikasi simulasi visualisasi teknik gerakan yoga berbasis mobile ini bisa dipakai di secara umum dan bermanfaat bagi semua masyarakat.
\end{abstract}

Kata Kunci: Multimedia, Luther-Sutopo, Android ,Visualisasi

Abstract

Nowadays there are lots of sports, one of them is yoga, yoga is very beneficial for physical and spiritual health. in modern times yoga is very less interested because of the lack of information about movement techniques in certain areas, thereby reducing the interest of the community in practicing the techniques of yoga movements. There needs to be a solution to this problem by creating a multimedia media in the form of visualization and simulation using a mobile-based, and using the Luther-sutopo method where the process is divided into 6 stages, namely: concept, design, material collecting, assembly, testing, distribution. So this multimedia development can be developed on a mobile basis. The use of media simulation and visualization of mobile-based multimedia makes it easier for users to find out yoga movement techniques because the form of simulation and viusalization of attractive yoga movements can increase people's interest. It is expected that in this visualization simulation application mobile-based yoga movement techniques can be used in general beneficial for all people.

Keywords: Multimedia, Luther-Sutopo, Android, Visualization

\section{PENDAHULUAN}

Yoga berasal dari istilah yuj dan yoking (bahasa sansekerta) yang berarti menyatu, penyatuan tersebut memiliki arti penyatuan secara harmonis dari yang terpisah bisa dengan alam ataupun dengan sang pencipta, yoga sendiri juga digunakan untuk aktivitas seperti meditasi, latihan postur, menghilangkan stress, melatih kekuatan fisik dan meningkatkan kualitas hidup, yoga memiliki berbagai aliran yang sesuai dengan kebutuhan individu Hatta Yoga, Bhagavad Gita, Yogasutra, dan sebagainya, saat ini Hatta Yoga merupakan aliran yoga yang paling populer dibandingkan aliran lainnya[1].

Pada zaman modern latihan yoga sangat dibutuhkan oleh masyarakat modern yang kehidupannya kompetitif, kehidupan yang kompetitif menyebabkan masyarakat sulit untuk menikmati hidup karena pikiran fokus pada pekerjaan serta mudah stress akibat kesibukan yang padat [1]. kebanyakan aktivitas yoga saat ini sering dilakukan oleh orang dewasa saja dan sedikit remaja yang melakukan aktivitas yoga, serta aktivitas gerakan yoga banyak dipraktekkan oleh para wanita dan hanya sedikit para pria melakukan aktivitas yoga dikarenakan kurangnya pengetahuan untuk belajar teknik gerakan yoga, dan kurang gencarnya berbagai media cetak, internet, TV dan sebagainya dalam mempromosikan aktivitas yoga, padahal yoga sangat bagus dilakukan oleh semua orang karena bermanfaat buat jasmani dan rohani. Oleh Karena itu perlu adanya sebuah media multimedia berbentuk simulasi dan visualisasi dalam memberi sebuah pembelajaran dan informasi kepada semua orang mengenai pentingnya melakukan aktivitas yoga[1].

Simulasi dan visualisasi dapat membantu masyarakat untuk mengetahui informasi, Simulasi menampilkan visual dari tiruan yang terdapat di kehidupan nyata dengan bantuan sistem komputer dan di sederhanakan dengan menggunakan visualisasi yang mudah diterima masyarakat sehingga dapat menghemat biaya, tenaga, dan waktu yang dikeluarkan.

Metode Multimedia sekarang ini banyak sekali mulai dari villamil - Molina ,Vaughan, luther-sutopo dan sebagainya, salah satu metode yang efektik dan effisien dalam pengembangan multimedia adalah dengan metode multimedia pengembangan luther sutopo dimana metode ini memiliki 6 tahap yaitu : concept, design, material collecting, assembly, testing, dan distribution[2]. Tahap-tahap ini tidak harus berurutan, tahap-tahap tersebut bisa berubah posisi hanya saja pada tahan concept harus diposisi awal karena tanpa adanya konsep metode multimedia ini tidak berjalan dengan baik[2].

berbeda dengan metode lainnya misalnya villamil-molina, metode ini menggunakan berbagai tahap yang salah satu tahapnya pada preproduction harus mengembangkan kontrol berbagai anggaran terhadap pengembangan multimedia,dan juga untuk pada tahap postproduction aplikasi multimedia hanya dikemas dalam bentuk penulisan ke CD/DVD atau dipublikasikan ke internet sebagai website saja[3].

Dalam Permasalahan ini diperlukan jalan keluar dengan membuat sebuah media Multimedia yang berbentuk visualisasi dan simulasi menggunakan berbasis mobile, Sehingga Media Multimedia ini bisa membuat pengguna lebih mudah 


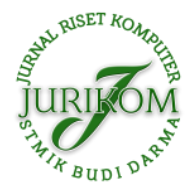

JURIKOM (Jurnal Riset Komputer), Vol. 7 No. 2, April 2020 e-ISSN 2715-7393 (Media Online), p-ISSN 2407-389X (Media Cetak) DOI 10.30865/jurikom.v7i2.1944

dalam melakukan kegiatan aktivitas yoga dikarenakan bentuk simulasi dan viusalisasi gerakan yoga yang menarik bisa meningkatkan minat orang-orang dalam melakukan aktivitas yoga tersebut dengan multimedia berbasis Mobile.

Dari uraian di atas penulis membuat sebuah terobosan dalam mendalami sebuah teknik gerakan yoga yang efektif dan efisien dengan menggunakan berbasis mobile serta menggunakan simulasi dan visualisasi multimedia yang baik, sehingga bisa mengajak masyarakat lain untuk mempraktekkan aktivitas yoga sendiri dengan menggunakan berbasis mobile tersebut.

\section{METODE PENELITIAN}

\subsection{Simulasi}

Simulasi merupakan teknik penyusunan suatu model dari keadaan yang nyata dan kemudian dilakukan percobaan pada model tersebut[4] , Dengan kata lain simulasi adalah sebuah tiruan dari sistem di komputer dengan menggunakan model tertentu dan dapat memprediksi keputusan yang digunakan berdasarkan simulasi sehingga menghemat biaya, tenaga, dan waktu yang dikeluarkan.

Simulasi dapat diterapkan dalam menganalisa suatu masalah yang rumit dari sistem dan penggunaan teknik analisa yang ada sangat terbatas dengan melakukan berbagai tahapan prosedur, adapun tahapan prosedur dalam melakukan simulasi, diantaranya[4] :

1. Formulasi Masalah

2. Menentukan Kelayakan Simulasi

3. Menyusun Model Simulasi

4. Memvalidasi Model

5. Menerapkan Simulasi

6. Analisa Hasil Simlasi

\subsection{Visualisasi}

Berbagai macam definisi mengenai visualisasi menurut para ahli pada refrensi penelitian ini definisi visualisasi adalah menggunakan teknologi komputer sebagai pendukung untuk melakukan penggambaran data visual yang interaktif untuk memperkuat pengamaatan, serta visualisasi itu sendiri ialah metode menggunakan komputer untuk mentransformasikan simbol menjadi geometrik dan memungkinkan peneliti dalam hal mengamati simulasi komputasi yang dapat memperkaya proses penemuan ilmiah sehingga dapat mengembangkan pemahaman yang lebih dalam dan tak terduga[4].

Dalam menuyusun sebuah bentuk visualisasi terdapat berbagai hal yang dapat membentuk sebuah visualisasi diantaranya[5] :

1. Penggunaan tanda-tanda (sign)

2. Gambar (drawing)

3. Lambang dan simbol

4. Ilmu dan penulisan huruf ( tipografi)

5. Ilustrasi dan warna

Dari definisi menurut para ahli maka dapat disimpulkan bahwa visualisasi adalah suatu teknik yang digunakan untuk memberikan informasi dengan metode terbaik dengan bentuk visual menggunakan komputer sebagai pendukung untuk memudahkan penerima dalam melakukan analisa dan memahami informasi.

\subsection{Metode Pengembangan Multimedia Luther-Sutopo}

Metode pengembangan multimedia terdiri dari enam tahap yaitu : concept (konsep), design (pendesainan), material collecting (pengumpulan materi), assembly (pembuatan), testing (pengujian), dan distribution (pendistribusian). Keenam tahap ini tidak harus berurutan dalam praktiknya, tahap-tahap tersebut dapat saling bertukar posisi. model pengembangan Penelitian ini dibuat berdasarkan metode pengembangan multimedia luther sutopo yang dimodifikasi dari metode luther dalam siklus MDLC[2]

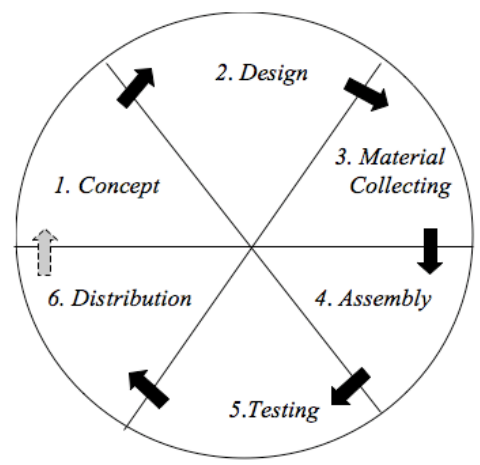

Gambar 1. Metode Pengembangan Multimedia Luther-Sutopo 


\section{Concept}

Tahap konsep adalah tahap untuk menentukan tujuan dan siapa pengguna program. Selain itu menentukan macam aplikasi (presentasi, interaktif, dan lain lain) dan tujuan aplikasi (hiburan, pelatihan, pembelaran, dan sebagainya) harus berpengaruh pada nuansa multimedia sebagai pencerminan dari identitas organisasi yang mengingikan informasi sampai pada pengguna akhir. Dasar aturan untuk perancangan juga ditentukan pada tahap ini, misalnya ukuran aplikasi, target, dan lain-lain, output dari tahap ini biasanya berupa dokumen yang bersifat naratif untuk mengungkapkan tujuan projek yang ingin dicapai. Berdasarkan konsep multimedia yang akan dikembangkan, maka harus membuat deskripsi dari konsep yang akan dibuat[2].

2. Design

Design (perancangan) adalah tahap membuat spesifikasi mengenai arsitektur program, gaya, tampilan dan kebutuhan material/bahan untuk program. Spesifikasi dibuat serinci mungkin sehingga pada tahap berikutnya, yaitu material collecting dan assembly pengambilan keputusan tidak perlu, pada tahap ini harus menggunakan storyboard untuk menggambarkan deskripsi tiap scene, dengan mencantumkan semua objek multimedia dan tautan scene yang lain dengan bagan alir untuk menggambarkan aliran dari satu scene ke scene yang lain[2].

a. Storyboard

Storyboard merupakan pengorganisasi grafik seperti sederan ilustrasi gambar atau text yang ditampilkan untuk keperluan visualisasi awal dari suatu file, animasi, atau media interaktif . perancangan storyboard akan menjadi acuan dalam pembuatan tampilan pada tahap implementasi

b. Struktur Navigasi

Struktur Navigasi yang digunakan adalah model hierarki dengan modifikasi sesungguhnya sesuai dengan tahap konsep yang akan dibuat, hasil dari perancangan struktur navigasi berupa diagram hierarki yang menggambarkan hubungan antar scene.

3. Material Collecting

Material Collecting adalah tahap dimana mengumpulkan bahan semua objek atau bahan multimedia dibuat berdasarkan sesuai dengan kebutuhan. Bahan-bahan tersebut bisa gambar, foto, animasi, video, audio dan lain-lain yang diperoleh secara gratis bisa melalui internet, Tahap ini dapat dikerjakan paralel dengan tahap assembly. Pada beberapa kasus, tahap material collecting dan tahap assembly akan dikerjakan secara linear tidak paralel.

4. Assembly

Tahap Assembly (pembuatan) adalah tahap pembuatan semua objek atau bahan multimedia. Pembuatan aplikasi didasarkan pada tahap desain, tahap ini menggunakan berbagai aplikasi pendukung dalam pembuatan visualisasi, objek gambar, dan lainnya seperti aplikasi blender $3 d$, eclipse

5. Testing

Tahap Testing Dilakukan setelah selesai tahap pembuatan (assembly) yaitu dengan menjalankan aplikasi/program. Tahap pertama dalam pengujian ini menggunakan alpha test yang mengujiannya dilakukan oleh pembuat atau lingkungan pembuatnya sendiri,

6. Distribution

Tahapan dimana aplikasi disimpan dalam suatu media penyimpanan, kemudian didistribusikan kepada pihak pengguna. Pada tahap ini jika media penyimpanan tidak cukup menampung aplikasinya, maka dilakukan kompresi terhadap aplikasi tersebut, tahap ini juga disebut tahap evaluasi untuk pengembangan produk yang sudah jadi agar menjadi lebih baik, hasil evaluasi dapat digunakan sebagai masukan untuk tahap concept pada produk selanjutnya[2].

\section{ANALISA DAN PEMBAHASAN}

Analisis simulasi visualisasi teknik gerakan yoga yang berjalan saat ini tidak efektif dan effisien seperti untuk mengetahui gerakan yoga orang-orang harus menunggu instrukur yang menjelaskan panjang lebar dan itu sangat membosankan, dan visualisasi yang terdahulu sangat tidak efektif bahkan cenderung tidak bisa membangkitkan minat orang untuk mempelajari teknik gerakan yoga karena simulasi visualisasinya hanya menggunakan manusia tidak menggunakan animasi yang interaktif. Animasi-animasi yang disajikan akan menjadikan simulasi dan memvisualisasikan teknik gerakan-gerakan yoga khususnya untuk postur berdiri.

Adapun analisa tahapan proses simulasi visualisasi teknik gerakan yoga yang akan dibuat sebagai berikut :

1. Merumuskan proses ataupun tahapan mengenai berbagai macam teknik gerakan yoga untuk postur berdiri

2. Menyederhanakan teknik gerakan yoga dengan mengambil sebagian gerakan yoga postur berdiri sehingga user lebih mudah dan cepat menerima informasi mengenai teknik gerakan yoga yang akan dibuat nantinya

3. Merancang tampilan visualisasi teknik gerakan yoga yang diambil dari berbagai sumber serta menampilkan visualisasi teknik gerakan yoga yang bersifat modern, simpel, dan sederhana

4. Membuat desain teknik gerakan yoga dengan menggunakan software blender 3D dan dibuat melalui tahap modelling serta menampilkan cara teknik gerakan yoga berdasarkan setiap view pergerakan yoga

5. Memindahkan hasil dari simulasi visualisasi teknik gerakan yoga dari aplikasi blender 3D ke media dalam bentuk video berformat mp4 dan ditampilkan pada proses pembuatan aplikasi di Software Eclipse serta disimpan berbentuk file hasil untuk di instalasi ke dalam smartphone user. 
Dalam metode pengembangan multimedia luther-sutopo terdapat berbagai tahap-tahap yang harus dibuat pada pembuatan simulasi dan visualisasi yaitu : konsep, design (perancangan), material collecting (pengumpulan materi), assembly (pembuatan), testing (pengujian), dan pendistribusian. Tahap ini akan digunakan dalam simulasi visualisasi teknik gerakan yoga dengan metode pengembangan multimedia luther-sutopo berbasis mobile. Berikut tahap demi tahap dalam menggunakan metode ini :

a. Konsep

Pada tahap konsep ini akan mendefinisikan mengenai identifikasi pengguna aplikasi, jenis aplikasi, tujuan aplikasi dan hal-hal umum yang berkaitan dengan teknik gerakan yoga yang akan dikembangkan

Tabel 1. konsep simulasi visualisasi teknik gerakan yoga berbasis mobile

\begin{tabular}{ll}
\hline Judul & : simulasi visualisasi teknik gerakan yoga berbasis mobile \\
\hline Audiens & $:$ masyarakat umum \\
Tujuan & $:$ untuk membangkitkan minat masyarakat mengenai teknik gerakan yoga \\
Durasi & $: \pm 5$ menit \\
Materi & - gambar mengenai yoga berformat .jpg \\
& - video berformat mp4 sebagai media simulasi dan visualisasi dengan animasi 3D \\
& - teks untuk menjelaskan mengenai tata cara gerakan yoga \\
Interaktivitas & $:$ Jeda, kontiniu, skip, tombol perpindahan dari scene ke scene yang lain, tombol keluar, \\
Animasi & $:$ animasi 3D teknik gerakan yang dibuat dari blender dan di render ke bentuk video \\
Simulasi & $:$ Simulasi ini berbentuk visualisasi teknik gerakan yoga pada postur berdiri \\
\hline
\end{tabular}

b. Design

Pada tahap design/perancangan ini akan dibuat tiap-tiap scene dalam bentuk model simulasi, storyboard, struktur navigasi dan pemodelan pada penelitian ini. Storyboard ini akan menggambarkan proses dari scene-scene yang akan dibuat sesuai dengan perancangan pada tahap sebelumnya, pada perancangan storyboard ini akan menjelaskan scene dan mendeskripsikan apa saja yang terdapat pada pemodelan ini dan akan disampaikan secara keseluruhan mengenai teknik gerakan yoga berbasis mobile

Tabel 2. Storyboard simulasi visualisasi teknik gerakan yoga berbasis mobile

\begin{tabular}{|c|c|c|}
\hline Scene & Deskripsi & Link \\
\hline Halaman Home & $\begin{array}{l}\text { Halaman intro merupakan halaman pembuka, dalam halaman ini terdapat } \\
\text { gambar gerakan yoga dan tombol simulasi, tombol about, dan tombol keluar. }\end{array}$ & Scene 1.0 \\
\hline Halaman Simulasi1 & $\begin{array}{l}\text { Simulasi teknik gerakan yang divisualisasikan dan dibuat dalam animasi 3D } \\
\text { dengan format video dan menuju pada visualisasi gerakan yoga postur berdiri } \\
\text { dengan gerakan tadasama (postur gunung), dengan waktu 15-30 detik dan } \\
\text { didalam scene ini terdapat tombol next dan exit. Jika tombol next maka akan } \\
\text { menuju ke scene } 2.1 \text {, sedangkan tombol exit maka menuju ke scene } 1.0\end{array}$ & Scene 2.0 \\
\hline Halaman About & $\begin{array}{l}\text { Halaman ini berisikan tentang profil dari pembuat aplikasi teknik gerakan yoga } \\
\text { berbasis mobile dan halaman ini terdapat tombol back untuk menuju scene } 1.0\end{array}$ & Scene 3.0 \\
\hline Keluar & $\begin{array}{l}\text { Tombol untuk keluar dari aplikasi teknik gerakan yoga dengan metode } \\
\text { multimedia pengembangan luther-sutopo berbasis mobile }\end{array}$ & Scene 4.0 \\
\hline Halaman Simulasi2 & $\begin{array}{l}\text { Halaman ini berisikan simulasi teknik gerakan yoga yang divisualisasikan dan } \\
\text { dibuat dalam animasi 3D dengan format video dan langsung menuju pada } \\
\text { visualisasi gerakan yoga postur berdiri dengan gerakan padahastasana (berdiri } \\
\text { menekuk badan ke depan), dengan waktu simulasi } 15-30 \text { detik dan didalam } \\
\text { scene ini terdapat tombol next, back, dan exit. Pada tombol next akan menuju } \\
\text { ke scene } 2.2 \text { jika tombol back maka menuju scene } 2.0 \text {, jika tombol exit maka } \\
\text { menuju ke scene } 1.0\end{array}$ & Scene 2.1 \\
\hline Halaman Simulasi3 & $\begin{array}{l}\text { Halaman ini berisikan simulasi teknik gerakan yoga yang divisualisasikan dan } \\
\text { dibuat dalam animasi 3D dengan format video dan menuju pada visualisasi } \\
\text { gerakan yoga postur berdiri dengan gerakan trikonasana (postur segitiga), } \\
\text { dengan waktu simulasi } 15-30 \text { detik dan didalam scene ini terdapat tombol next, } \\
\text { back, dan exit. Pada tombol next akan menuju ke scene } 2.3 \text { jika tombol back } \\
\text { maka menuju scene } 2.1 \text {, jika tombol exit maka menuju ke scene } 1.0\end{array}$ & Scene 2.2 \\
\hline Scene Simulasi4 & $\begin{array}{l}\text { Berisikan simulasi teknik gerakan yoga yang divisualisasikan dan dibuat dalam } \\
\text { animasi 3D dengan format video dan menuju pada visualisasi gerakan yoga } \\
\text { postur berdiri dengan gerakan ardha chandrasana (postur bulan sabit), dengan } \\
\text { waktu simulasi } 15-30 \text { detik dan didalam scene ini terdapat tombol next, back, } \\
\text { dan exit. Pada tombol next akan menuju ke scene } 2.4 \text { jika tombol back maka } \\
\text { menuju scene } 2.2 \text {, jika tombol exit maka menuju ke scene } 1.0\end{array}$ & Scene 2.3 \\
\hline
\end{tabular}


Halaman Simulasi5 Halaman ini berisikan simulasi teknik gerakan yoga yang divisualisasikan dan

Scene 2.4

dibuat dalam animasi 3D dengan format video dan menuju pada visualisasi gerakan yoga postur berdiri dengan gerakan parsvottanasana (postur ekstrem dan menekuk ke depan), dengan waktu simulasi 15-30 detik dan didalam scene ini terdapat tombol back, dan exit. Pada tombol back maka menuju scene 2.3, jika tombol exit maka menuju ke scene 1.0

Struktur navigasi yang digunakan dalam metode ini adalah struktur hirearki dengan merancang hubungan antar scene dengan yang lainnya sesuai pada perancangan storyboard teknik gerakan yoga berbasis mobile.

c. Material collecting

Pada tahap pengumpulan materi dari penelitian ini , materi yang diambil harus berhubungan dengan penunjang untuk pembuatan simulasi visualisasi teknik gerakan yoga berbasis mobile, berikut adalah materi yang diambil sesuai dengan penelitian ini

1. Teknik gerakan yoga postur berdiri yang diambil dari studi pustaka berupa gambar berformat Jpg, yang berguna untuk menampilkan gambar pada halaman pembuka dan halaman tutorial

2. Animasi 3D yang dibuat dengan format video mp4 dan digunakan untuk mensimulasikan visualisasi teknik gerakan yoga

3. Aplikasi gratis blender 3D untuk membuat animasi 3D sesuai dengan teknik gerakan yoga postur berdiri

4. Aplikasi open source eclipse sebagai media berbasis mobile tempat menampilkan simulasi visualisasi teknik gerakan yoga postur berdiri.

d. Assembly

Pada tahap ini seluruh material collecting simulasi visualisasi teknik gerakan yoga berbasismobile yang sudah diambil sebelumnya maka proses selanjutnya membuat simulasi visualisasi untuk teknik gerakan yoga postur berdiri dan dibuat pada aplikasi blender 3D sesuai panduan gerakan yoga

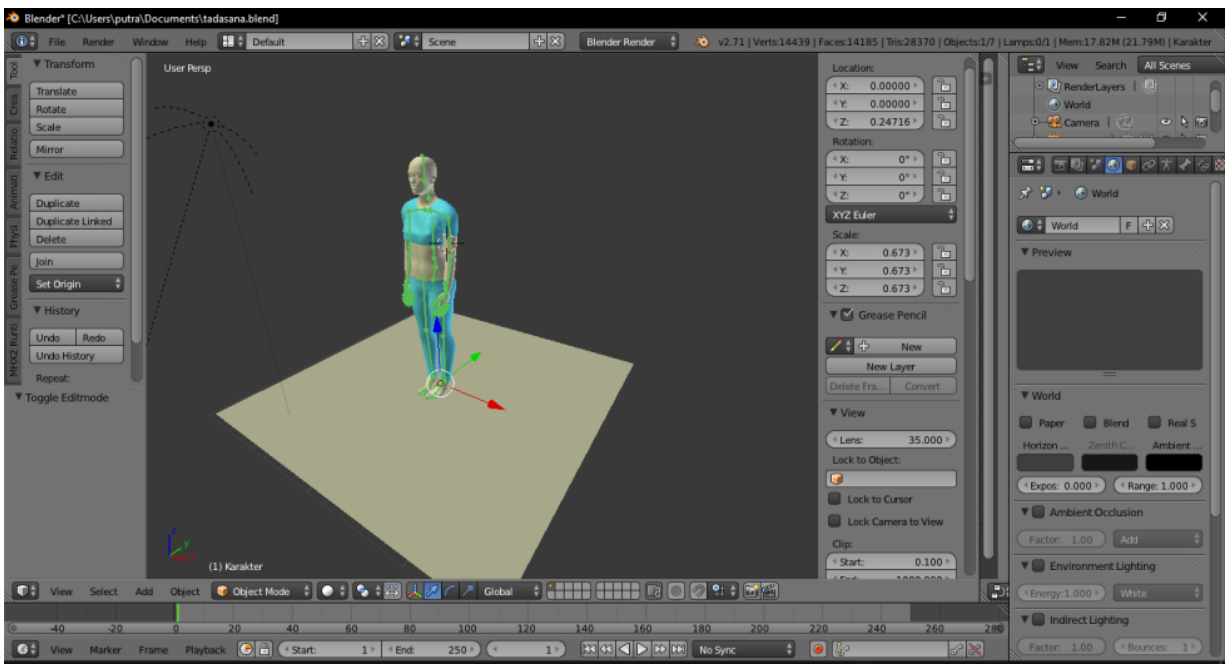

Gambar 2. Pembuatan Material Collecting

e. Testing

Tahap ini adalah tahap pengujian dari simulasi visualisasi teknik gerakan yoga berbasis mobile, pada tahap ini sebelumnya di buat pada Software Eclipse yang terdapat pada komputer pembuat lalu dihasilkan file baru sehingga bisa disalurkan ke pengguna akhir.

f. Distribution

Tahap ini adalah tahap pendistribusian hasil dari program aplikasi dari simulasi visualisasi teknik gerakan yoga yang dibuat pada program Eclipse sehinga menghasilkan file berekstensi apk lalu disalurkan ke pengguna/User untuk bisa di install di dalam android

\subsection{Implementasi}

Aplikasi simulasi visualisasi teknik gerakan yoga dengan metode pengembagan multimedia luther-sutopo berbasis mobile telah dirancang pada bab sebelumnya akan di buat dengan software eclipse, dimana hasil program yang dijalankan akan berekstensi apk yang merupakan hasil file dari software eclipse, dan tahap selanjutnya menginstalasi file apk ke dalam android untuk dijalankan tanpa harus menggunakan software eclipse lagi.

Tampilan menu utama merupakan halaman yang pertama kali muncul setelah program dijalankan, dalam tampilan menu utama terdapat tombol simulasi, about, dan keluar. 


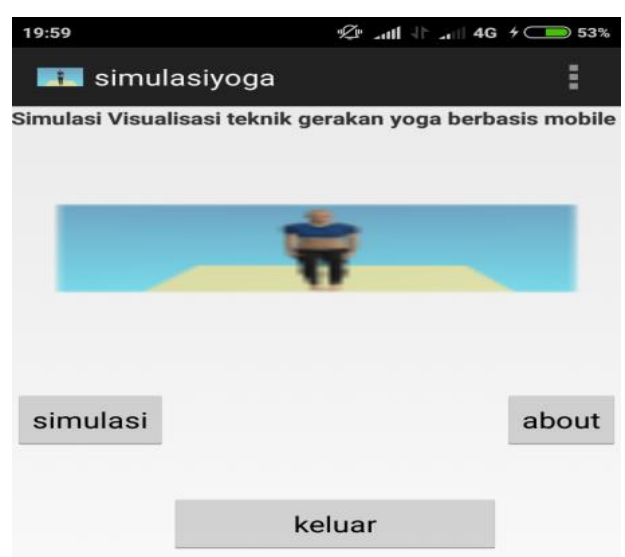

Gambar 3. Tampilan Menu Utama Pada Aplikasi Simulasi Visualisasi Teknik Gerakan Yoga

Pada menu simulasi terdapat tombol play untuk menjalankan simulasi dan tombol untuk selanjutnya dan keluar

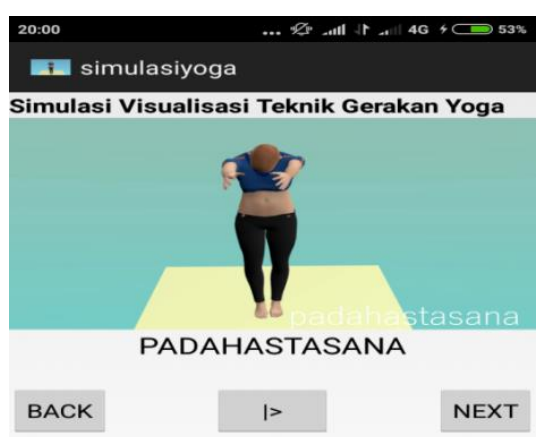

EXIT

Gambar 4. Tampilan Menu Simulasi Pada Aplikasi Simulasi Visualisasi Teknik Gerakan Yoga

Pada menu about akan menampilkan profil dari pembuat aplikasi dan tombol untuk kembali ke menu utama

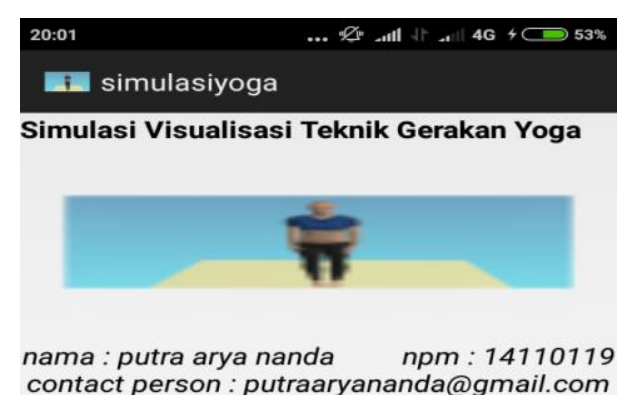

contact person : putraaryananda@gmail.com

Gambar 5. Tampilan Menu About Pada Aplikasi Simulasi Visualisasi Teknik Gerakan Yoga 


\section{KESIMPULAN}

Berdasarkan dari pembahasan dan evaluasi dari bab-bab sebelumnya, maka dapat diambil beberapa kesimpulan sebagai berikut :

1. Menampilkan gerakan yoga dengan membuat konsep animasi yang dapat mengarahkan setiap pergerakan yoga sehingga dapat meningkatkan minat dalam mengetahui gerakan yoga.

2. Penerapan metode multimedia luther-sutopo pada simulasi visualisasi teknik gerakan yoga dapat membantu memudahkan dalam menyajikan aplikasi yang menarik dan tertata rapih sehingga user tertarik dengan yoga.

3. Aplikasi bisa langsung di instalasi di smartphone mobile seperti android tanpa harus membuka dengan aplikasi eclipse lagi, karena sudah ada instalasi berbentuk file Apk sehingga dapat memudahkan user dan menggunakan aplikasi blender v2.72

\section{REFERENCES}

[1] A. S. Kinasih, "Pengaruh Latihan Yoga Terhadap Peningkatan Kualitas Hidup," Buletin Psikologi, vol. 18, pp. 1-12, 2010.

[2] I. Binanto, Multimedia Digital Dasar-Dasar Teori dan Pengembangannya, Yogyakarta: Andi Offset, 2010.

[3] I. Binanto, "Tinjauan Metode Pengembangan Perangkat Lunak Multimedia Yang Sesuai Untuk Mahasiswa Tugas Akhir," Seminar Nasional Rekayasa Perangkat Komputer Dan Aplikasinya.

[4] S. M. Dr. Kirman Siregar, Simulasi Dan Pemodelan (Aplikasi Untuk Keteknikan Pertanian), Yogyakarta: Deepublish, 2016.

[5] Mauludi dan R. Yuniar, "PT. Pelabuhan Indonesia III (Persero)," Visualisasi Informasi Berbasis Web Untuk Reporting Pada Website E-Rekrutmen PT. Pelabuhan Indonesia III (Persero), 2013. [Online]. Available: http://sir.stikom.edu/938/. [Diakses 2019].

[6] H. Haydi, "Visualisasi Konsep Umum Sisitem Pakar Berbasis Multimedia," Riau Journal Of Computer Science, vol. 3, no. 1, pp. 17-22, 2017.

[7] K. Yuliani dan M. S. Shanty, The Power Of Yoga, Yogyakarta: Bhafana Publishing, 2017.

[8] P. Sindhu, Panduan Lengkap Yoga: Untuk Hidup Sehat Dan Seimbang, Bandung: QANITA, 2014.

[9] G. P. A. Oka, Media Dan Multimedia Pembelajaran, Yogyakarta: Deepublish, 2017.

[10] “Belnder," [Online]. Available: https://www.blender.org/foundation/history/. [Diakses 16 Juli 2018].

[11] A. B. Mutiara dan R. Refianti, Desain Pemodelan Grafik : Pemodelan Pohon, Yogyakarta: Gunadarma, 2014.

[12] R. A. S dan M. shalahuddin, Rekayasa Perangkat Lunak (Terstruktur Dan Berorientasi Objek), Bandung: Informatika, 2016.

[13] N. S. H, Android Pemrograman Aplikasi Mobile Smartphone Dan Tablet Pc Berbasis Android, Bandung: Informatika, 2015.

[14] M. A Satyaputra dan S. E Maulina Aritonang, Java For Beginner With Eclipse 4.2 Juno, Jakarta: PT Elex Media Komputindo, 2012.

[15] Y. Amrizal dan R. Kurniati, "Game Aritmatika Berbasis Android,” Jurnal Inovtek Polbeng - Seri Informatika, vol. 1, no. 2 , 2016.

[16] M. Dr.Ir Wahyuni, Sistem Berkas, Yogyakarta: Andi Offset, 2013. 